\title{
BLIND ALLEYS IN THE CONTROVERSY OVER THE PAUL OF HISTORY
}

\author{
Mark A. Seifrid
}

\begin{abstract}
Summary
E.P. Sanders' reading of Paul against the backdrop of 'covenantal nomism' is badly flawed, since it obscures Paul's coming to understand the cross as working the justification of the ungodly. Two important extensions of Sanders' paradigm also fail to illumine Paul in his context. 'Works of the Law' are not simply ethnic boundaries, as J.D.G. Dunn claims, but marks of piety as well. N.T. Wright's proposal that Christ provided the solution to Paul's experience of exile reverses the manner in which exilic language appears in Paul's letters. Contrary to the common assumption, Luther's theology of the cross and justification is not barren or irrelevant, and more closely accords with Paul than recent attempts to understand him.
\end{abstract}

If Ernst Käsemann were to re-enter the current debate over Paul's Jewish background and theology, I imagine that he might choose a title along the lines of the one I have given this essay. ${ }^{1}$ His stentorian voice might do some good. Other voices which have dissented from the 'new perspective' on Paul in its various forms since the ushering in of the 'post-Sanders era' have not been heard sufficiently, drowned out perhaps by a chorus of affirmation. That is not to suggest that the 'new perspective' has been entirely deleterious in its effects. It should be viewed as part of a recent impulse across the discipline of theology to come to terms with the Reformers' article of justification in this generation, a necessary task. And it has called

1See N.T. Wright's Auseinandersetzung with Käsemann, 'The Paul of History and the Apostle of Faith', TynB 29 (1978) 61-88. The title is drawn from Käsemann's essay 'Sackgassen im Streit um den historischen Jesus' in Exegetische Versuche und Besinnungen (Göttingen: Vandenhoeck \& Ruprecht, 1964) 2:31-68. 
attention to the social dimension of justification by faith, a central facet of Paul's arguments which must not lie neglected. Yet while providing fresh impulses, many advocates of the newer reading of Paul have failed to wrestle with the character of the Reformation debate. A so-called 'Lutheran' reading of Paul has been dismissed, even by exegetes within the Lutheran tradition, without an adequate acknowledgement -or perhaps in some cases knowledge-of what moved Luther and other Reformers to regard justification by faith alone as the 'first and chief' article of confession of the Gospel. Ever increasing specialisation within the field of biblical studies has made us strangers to large stretches of the Christian tradition. We simply must find our way to a critical appropriation of the past, particularly in regard to this topic.

In this instance the recommendation to retrace our steps holds not merely in a theological sense, but also in an exegetical and historical one. Current efforts at massive revision of our understanding of Paul have missed crucial signposts which might have prevented the interesting, but unproductive detour which much of current study of Paul seems intent on pursuing. The details of the debate have been outlined adequately in a number of recent surveys. ${ }^{2}$ It seems appropriate now to bring some pivotal points front and centre for consideration, and to place the exegetical disputes in a broader context. Virtually all aspects of the 'new perspective', in both its spheres of inquiry-early Judaism and Pauline theology-have been offered before. If it is new, it is so by virtue of its linking a Pharisee who knew divine grace and mercy with the apostle who was sent by Christ to the Gentiles. Everything depends on how one sorts out the relation between this 'covenantal nomism' of Paul's past and his transforming

2Douglas Moo, 'Paul and the Law in the Last Ten Years', SJT 40 (1987) 287307; Stephen Westerholm, Israel's Law and the Church's Faith: Paul and His Recent Interpreters (Grand Rapids: Eerdmans, 1988) 1-100; Frank Thielman, From Plight to Solution (NTSupp 61; Leiden: Brill, 1991) 339-353; P.T. O'Brien, 'Justification in Paul and Some Crucial Issues of the Last Two Decades' in D.A. Carson (ed.), Right with God: Justification in the Bible and the World (Carlisle: Paternoster, 1992) 69-95; Donald A. Hagner, 'Paul and Judaism: The Jewish Matrix of Early Christianity: Issues in the Current Debate', Bulletin for Biblical Research 3 (1993) 111-130. 
faith and work in Christ. Sanders' Paul and Palestinian Judaism originally provided only the framework: Paul the Jew rejected God's covenantal mercies because they were not 'Christianity'. ${ }^{3}$ Dunn has been in the forefront of building an explanatory bridge for the gap in the 'new perspective' ${ }^{4}$ In his reading, Paul's arguments on justification chiefly concern his opposition to Jewish exclusivity. The discontinuity between Paul and his past should be understood primarily as his becoming an advocate for the inclusion of Gentiles in the people of God, not as a release from a guilty conscience or a new understanding of divine mercy. More recently, Wright has claimed to find a continuity between Paul the apostle and early Jewish hopes for God's saving covenant-faithfulness. ${ }^{5}$ According to him, Paul's faith in Christ resolved a fundamental longing shared by many among the Jewish people: the death and resurrection of the Messiah brought to an end the continuing exile of the people of God. Arguably, all other attempts to make sense of Paul and his arguments on the Law and justification within the framework of the 'new perspective' are generically related to the twin themes of ethnicity and the end of exile, which Dunn and Wright have introduced. 6 Despite their improvements on Sanders' work, these two proposals lead into 'blind alleys' because they follow a path already mislaid.

Some central elements of Sanders' work on early Judaism serve his purpose of comparison with Paul rather poorly. The category of 'covenantal nomism' becomes relatively meaningless for describing the soteriology of early Jewish

3E.P. Sanders, Paul and Palestinian Judaism: a Comparison of Patterns of Religion (Philadelphia: Fortress, 1977) 474-511.

4See especially the collection of essays: James D.G. Dunn, Jesus, Paul, and the Law: Studies in Mark and Galatians (London: SPCK, 1990); Sanders has moved to close the gap in a similar way in his Paul, the Law, and the Jewish People (Philadelphia: Fortress, 1983) 154-160.

5See N.T. Wright, The New Testament and the People of God (Minneapolis: Fortress, 1992) 268-279; The Climax of the Covenant (Minneapolis: Fortress, 1991) 258-267.

6Some like Sanders, Paul, the Law, and the Jewish People and Heikki Räisänen, Paul and the Law (Philadelphia: Fortress, 1983) do not try to make sense of the 'whole' Paul, insisting that Paul's thought is inconsistent at various points. 
groups when the terms of the covenant are in dispute. ${ }^{7} \mathrm{I}$ have attempted elsewhere to show that Paul broke with a belief which this vague expression fails to articulate sufficiently: that the promise of mercy is given to those who are faithful to the covenant. 8 While remaining covenantal in structure, two representative early Jewish writings, the Community Rule from Qumran (1QS) and the Psalms of Solomon (Pss. Sol.), restrict the saving benefits of the covenant to a limited group within the nation. A measure of individualism enters here, especially in the Psalms of Solomon, since salvation is now contingent upon personal righteousness, adherence to the Law as it was interpreted within the community. ${ }^{9}$ Neither writing displays any lack of assurance on the part of the pious, or any indication that salvation was viewed as earned or deserved. The Psalms of Solomon attribute deliverance to divine mercy. The sola gratia stance of the Qumran materials is particularly evident.10 Paul's brief autobiographical statements about his life prior to his encounter with Christ conform to this pattern, especially as it appears in the Psalms of Solomon. He does not seem to have suffered from an 'introspective conscience' and most likely viewed the righteousness which was his through the Law as a gift from God. Nevertheless, the encounter with Christ worked a conversion in Paul. Faith in the crucified and risen Messiah led him to reject this very understanding of divine favour as a gift to the obedient. Through appropriation of early Christian traditions in which Jesus' death was interpreted as an atone-

${ }^{7}$ Covenantal nomism', as Sanders uses the expression, represents the idea that God saves those who by effort and intent remain in the covenantal relation established with Israel, where forgiveness and cleansing are provided, Paul and Palestinian Judaism, 422-423.

8 Mark A. Seifrid, Justification by Faith: the Origin and Development of a Central Pauline Theme (NovTSupp 68; Leiden: Brill, 1992). Timo Laato, working on the basis of Pauline anthropology and the structure of Paul's soteriology in comparison with Rabbinic materials arrives at basically the same conclusion. See his Paulus und das Judentum ( $\AA$ bo: Åbo Academy, 1991). I am told Mark A. Elliott has made the same point in an unpublished dissertation, The survivors of Israel (Aberdeen, Ph.D., 1993).

${ }^{9}$ See especially Ps. Sol. 9:4, 5.

${ }^{10}$ The Qumran writings, by virtue of their predestinarian stance are firmly sola gratia, but not sola fide. They differ from both the synergism of the medieval via moderna and the Pauline theology of the Reformers. 
ment for sin, he came to believe that salvation was mediated by the cross to the ungodly.

\section{1. 'Works of the Law' as Merely Ethnic Boundaries}

Discussion of Dunn's proposal that circumcision and food laws served as ethnic boundary markers has tended to focus, too narrowly in my view, on the meaning of the expression 'works of the Law'. We will briefly revisit that exegetical debate below. Here I wish to examine in broader strokes the claim that Paul rejected a Jewish 'national righteousness'. There is little doubt that circumcision, along with obedience to food and Sabbath laws, served Jews as 'boundary markers'. It is highly questionable however, that these 'boundary markers' symbolised mere national identity. Ethnic traditions bear values which provide cohesion and continuity in community life. And while early Judaism was a 'national' religion, it was nevertheless a religion.

That reality presses itself upon us from every angle in the early Jewish sources. It is not hard to find attestation that Jewish 'boundary markers' could transcend racial lines. One immediately thinks of Josephus' account of the circumcision of King Izates. Under the urging of a certain Eleazar, he was circumcised in order to become a Jew and, significantly, to ensure that he had truly conformed to the Law.11 The report, which is reflective of Josephus' views, indicates that the way was open for outsiders to become Jews. He states elsewhere, admittedly in an apologetic vein, that Moses the lawgiver took care

that we should not begrudge the things of the household (oikci $\alpha$ ) to those who choose to share them. For as many as come to live under the same laws as us, when they come he gladly welcomes them, supposing that the household relation

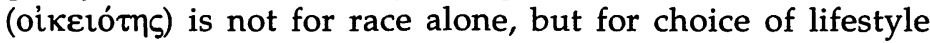
$\left(\right.$ (ßís). ${ }^{12}$

${ }^{11}$ Antiquities 20.34-48.

${ }^{12}$ Contra Apionem 2.210. I fail to see how Josephus' description of the welcome to Gentiles 'goes so far and no further', Wright, The New Testament and the People of God, 232. True, there is a limited participation 
This sentiment, although it does not remove the requirement of circumcision, is epitomised in the saying attributed to Hillel: 'Be one of the disciples of Aaron, who loves peace and pursues

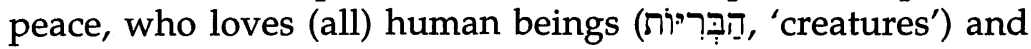
who brings them near to Torah.' 13

While it is true that Jews protected their traditions in distinctive practices, especially the 'boundary markers' of circumcision and Sabbath observance, and while there does not appear to have been widespread Jewish missionary activity in this period, there is good evidence that in many places Jews were receptive to those outsiders who in varying degrees associated themselves with the Jewish community. ${ }^{14}$ The ethical dimension of the language used to describe Gentile adherents to Judaism is unmistakable: 'God-fearer' is a designation for a pious Jew in the Scriptures, and the more Hellenistic term 'devout' ( $\theta \varepsilon \sigma \sigma \varepsilon \beta \eta$ 's) represents a general expression for religious devotion, applied to Jews and pagans as well.15

The recognition of 'righteous Gentiles' by some Jews led to a certain tension within Judaism regarding the importance of circumcision for salvation. Yet whatever their soteriology, those Jews who concerned themselves at all with Gentile participation in Judaism understood circumcision in ethical terms. Josephus' narrative of Izates' circumcision illustrates the situation well. Ananias and Eleazar disagree in their estimation of the importance of circumcision for Gentiles. The former judges that commitment to Jewish tradition is more important than the act of circumcision. Yet he does not regard Izates as having become a Jew without circumcision, or as having fully obeyed the Law: God will pardon Izates, because of the constraints of his situation. Eleazar, on the other hand, regards

for passing visitors, as there is for any 'family', but according to Josephus the door is open and the welcome mat out for those who want to stay: in contrast to the Lacedemonians, he claims, the Jews do not expel foreigners rather, 'we gladly welcome those desiring to share our (customs)', Contra Apionem 2.261.

$13 \mathrm{~m}$.Aboth 1.12 .

${ }^{14}$ See Scot McKnight, A Light Among the Gentiles: Jewish Missionary Activity in the Second Temple Period (Minneapolis: Fortress, 1991) esp. 11-48.

15 See Folker Siegert, 'Gottesfürchtige und Sympathisanten', Journal for the Study of Judaism 4 (1973) 109-164. 
the failure to be circumcised as an act of impiety. Despite their disagreement, they both look upon circumcision as a completion of the decision to worship God, a position which is reflected in Josephus' own estimation of the divine protection afforded Izates after his circumcision: 'The fruit which comes from godliness ( $\varepsilon \dot{\sigma} \sigma \varepsilon \varepsilon \varepsilon 1 \alpha$ ) is not lost for those who look to him, and trust in him alone.' 16

Circumcision here serves as a mark of faith and piety, not mere national identity. 17 Outsiders might have seen conversion to Judaism only as the transfer to another ethnos. For Jews like Josephus it signified the embrace of monotheism: the coming to faith in the one true God and the rejection of idolatry. 18 'Fearing God' did not in itself automatically secure a monotheistic commitment, circumcision effectively did.19 The other classic conversion story is that of Asenath, in which precisely the matter of monotheism is central. ${ }^{20}$ Israel's distinctiveness is regularly described in such terms elsewhere. ${ }^{21} \mathrm{Paul}$ and his Judaising adversaries in Galatia differed in soteriology, but like Ananias and Eleazar they represented an 'open' Judaism, ready to find a way to secure Gentile morality and the worship of the one God of Israel. As we have seen with Josephus, such groups and persons draw conceptual distinction between purity rituals and moral concerns, even where they are joined in practice. ${ }^{22}$ Circumcision symbolised not merely separation from other nations, but an ethically superior monotheism.

The religious character of Jewish 'boundary markers' becomes even clearer when we turn to writings which reflect tensions between various early Jewish factions. The judgement

\footnotetext{
16 Antiquities 20.48 .

${ }^{17}$ A similar sentiment appears in Contra Apionem 2.226, 'Let it be acknowledged: obedience to laws is a proof of virtue'.

${ }^{18}$ For Philo, too, circumcision represents self-control and the acknowledgement of one God as creator, Spec. Leg. 1.8-10.

${ }^{19}$ See Siegert, op. cit. 140-7.

20JosAsen 11-13. The intramural apologetic interest is apparent. How could Joseph marry a non-Jew? He didn't: she converted. The walls are being preserved, but so are the gateways.

${ }^{21}$ E.g. LetAris 134-43, Wis. Sol. 13-16; m.Abodah Zarah.

22See Mary Douglas, 'Critique and Commentary', in Jacob Neusner, The Idea of Purity in Ancient Judaism (SJLA 1; Leiden: Brill, 1973) 141.
} 
which we rendered on the expression 'covenantal nomism' applies as well to the category of 'national righteousness'. When one group of Jews regards another as 'outside the boundaries', the concept of 'nation' is subordinated to a larger idea of true religion and piety. This stance is a prominent feature of a number of the Qumran writings where the covenant is restricted to the community alone, and requires no elaboration here. ${ }^{23}$ It appears in other materials, although not in precisely the same manner. Where the sectarian stance recedes and intercourse with the larger society increases, the exclusivist use of terms like 'covenant' and 'Israel' disappears. A hope for 'national' salvation is retained by envisioning the nation as converted to righteousness. An alternative soteriological paradigm conditions the ethnic ideal. In the Psalms of Solomon this reshaping of covenantal theology takes the form of a distinction between 'the pious' (öolor) and 'the sinners' ( $\alpha \mu \alpha \rho \tau \omega \lambda$ oí). The former expression, along with similar terms, depicts the circle of the godly to whom the promises of Israel's salvation are assured. The latter term (and related expressions) more often than not refers to wayward Jews, whom the coming Messiah will cast out from the covenantal inheritance. ${ }^{24}$ The pattern is repeated elsewhere in varying forms. For all its severity, 4 Ezra retains its hope in covenantal mercies for the righteous (iusti). True, Uriel rejects any offer of mercy apart from the Law, but he tacitly affirms divine patience and grace toward those who turn toward it. A later vision in 4 Ezra affirms the hope that the Messiah will mercifully deliver the remnant at his judgement seat. ${ }^{25}$ The shift to ethical and individualistic categories in these materials subverts and restricts the 'national' ideal.

Placed side-by-side, the two features of early Judaism we have briefly examined make it impossible to sustain the claim that Jewish 'boundary markers' signalled exclusivism or national identity alone. I must confess considerable puzzlement

\footnotetext{
23See e.g. 1QS 1:7-8, 1:16-17; 10:10; CD 2:2; 3:13.

24Ps. Sol. 12:6, 17:3.

254 Ezra 7:133; 12:34. Here I am in disagreement with Bruce W. Longenecker, Eschatology and the Covenant: A Comparison of 4 Ezra and Romans 1-11 (JSNTS 57; Sheffield: JSOT Press, 1991). See my discussion of his treatment of 4 Ezra in Seifrid, op. cit., 133-5.
} 
that both Dunn and Wright, who recognise that some Jews could regard other Jews as outside the community of the elect on the basis of halakhah, regard distinctive practices as simply 'exclusivistic', borders without interior meaning. Insiders saw them as emblems of community values, especially fidelity to Torah and covenant. The מעשי התורה which those of the Qumran community are to offer to God as sacrifices are described elsewhere as מעשי טוב and joined with doing 'truth, righteousness, and justice'.26 Although we yet await the publication of $4 \mathrm{QMMT}$, the sectarian dispute it reflects is clearly of this nature. The מעשי התורה which divide the Qumran group from their adversaries represent what is right and good, and result in righteousness and blessing. ${ }^{27}$

If the reading which I have adopted is correct, the manner in which the Qumran community regarded its practices to function appears in an explicit manner in 1QS 11:2, 3: 'For I belong to the God of my vindication and the perfection of my way is in his hand with the virtue of my heart. And with my righteous deeds he will wipe away my transgressions...'28

\section{QFlor 1:7; 1QS 1:5.}

${ }^{27} \mathrm{~A}$ preliminary survey of the contents of the scroll appears in an article by Lawrence Schiffmann, 'The Temple Scroll and the systems of Jewish Law of the Second Temple Period' in G.J. Brooke (ed.), Temple Scroll Studies (JSPS 7; Sheffield: JSOT Press, 1989) 239-255. The terms of the dispute crucial for our interest may be found in the fragment 4 Q399. The one who composed this letter regarded certain 'works of the Law' as bringing blessing (מקצת מששי התורה שחשבנו לטוב לך, 'the sum of the works of the Law which we esteem as good for you', line 3). Disobedience in these matters involved the doing of evil (הרחיק ממך מחשבת רעה, 'put away from you an evil plan', line 5), while obedience held the promise of eschatological blessing (בשל שחשמח באחרית העת, 'in order that you may rejoice in the last time', line 6). The 'works of the Law' are characterised as 'doing what is right and good before God' and result in a divinely given righteousness and blessing (נחשבה לך לצדקה בעשותך הישר וטוב לפניו לטוב לך ולישראל, 'and it will be reckoned to you as righteousness when you do what is right and good before him, for your good and for that of Israel', line 7). ${ }^{28}$ Although the reading ובצדקותו ('in his righteousness') has been adopted universally as far as I can tell, reasons for reading ובצדקותי ('with my righteous deeds') are very strong (i.e. taking the final letter as a yodh; vav and yodh are indistinguishable in 1QS): (i) According to Qimron, The Hebrew of the Dead Sea Scrolls (HSS 29; Atlanta: Scholars Press, 1986) 33-35, Qumran scribes generally preserve the orthographic distinction between ? 
Even aside from this passage, it is clear that the Qumran community attributed a sanitising, atoning efficacy to its deeds. ${ }^{29}$ Yet it did so without in any way sacrificing its sola gratia stance: God was the source of these works and the salvation which accompanied them. The Psalms of Solomon do not attain to the same heights of grace as the Hodayoth, but they too know of an atonement through deeds of repentance (Ps. Sol. 3:3-8) and a saving righteousness gained by works ("丷 $\rho \gamma \alpha$, Ps. Sol. 9:4-5). The thesaurus operum accredited to Ezra (4 Ezra 7:77) is not an isolated phenomenon. Nor does it eliminate 'covenantalism' or notions of mercy, however qualified they might be.

If we understand Paul's rejection of 'the works of the Law' $^{\prime}$ in Galatians and Romans against this background, we overcome a number of interpretative difficulties. The debate between Dunn and his critics has centred on the place the problem of transgression holds in Paul's argument in Romans 2-4.30 While acknowledging that Paul addresses the issue of disobedience, Dunn now views a 'nationalistic righteousness' represented by ह̌ $\rho \alpha$ vó $\mu$ ov and epitomised in circumcision as the primary element of disobedience which Paul attacks. Yet Jewish 'boasting' is never treated as transgression in the rhetoric of the text. There is no call for repentance, no charge of guilt, simply a dismantling of the Jewish presumption of privilege. The rhetoric involving the term है $\rho \gamma \alpha$ vó $\mu$ ov is not forensic but deliberative, as the abundant use of the first-person plural in Romans 3-4 indicates. Once the charge that the Jew is guilty along with the rest of the world is established, Paul

and I; (ii) In the closing hymn of 1QS 10:8-11:22 only the ending (which refers to God) appears with feminine plural nouns; (iii) In the immediate context the word in question is surrounded by first-person singular endings requiring the use of $r$ if the reading 'his righteous deeds' is to be made evident; (iv) In all other instances of pronominal suffixes attached to the plural צרות which may be found in currently published Qumran materials, the plene form, with the 'reminiscent of the masculine construct state is retained. For further arguments see Seifrid, op. cit., 100-3.

${ }^{29}$ E.g. 1QS 3:6-8, 8:6-10, 9:4.

30See Thomas R. Schreiner, "'Works of Law" in Paul', NovT 33 (1991) 217244; J.D.G. Dunn, 'Yet Once More- "The Works of the Law": A Response', JSNT 46 (1992) 99-117. 
moves toward exploring the meaning of the cross alongside his audience. This shift in the form of argument appears precisely

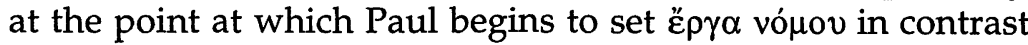
with Christ's saving work. ${ }^{31}$ Now that Dunn has allowed that transgression is a problem in Romans 2-3, he must come to terms with the evidence that Paul treats the 'works of the law' here not as transgression, but as a false way to righteousness. ${ }^{32}$

The significance of the expression है $p \gamma \alpha$ vó $\mu$ ov appears to be different from what either Dunn or his critics have proposed thus far. Dunn is surely correct in claiming that the है $\rho \gamma \alpha$ vó $\mu o v$ are visible and outward, in some way markers of Jewish identity. ${ }^{33}$ Paul uses this language only in the context of his debate with Judaism and alters his wording where he speaks of obedience to the Law by non-Jews. The uncircumcised person, for example, does not do 'the works of the Law', but 'keeps the just ordinances of the Law' ${ }^{34}$ The thesis that Paul is opposed to 'works in general' as a means of justification, claims just a shade too much. ${ }^{35}$ Theologically it represents a legitimate development of Paul's argument, but Paul was not thinking in categories broader than the Law itself. Without

${ }^{31}$ Rom. 3:20. Gal. 2:15-21, which introduces the cluster of occurrences of Ép $\alpha$ vó $\mu \mathrm{ov}$ in that letter, takes precisely the same form, and the subsequent use of this terminology in Gal. 3 is didactic. Paul wants to teach his audiences about the 'works of the Law'.

32Of course Paul regarded reliance on 'works of the Law' rather than the Gospel as disobedience, $c f$. Rom. 9:30-10:4.

${ }^{33}$ This observation may help in assessing the significance of the édेv $\mu \eta \dot{~}$ clause in Gal. 2:16. One wonders if the solution to the debate (viz., whether we have here a concessive clause such as generally appears with $\varepsilon \dot{i} \mu \eta$, or an adversative) lies in allowing that $\dot{\varepsilon} \alpha \dot{\alpha} \nu \mu \eta \dot{~ i n t r o d u c e s ~ a n ~}$ (elliptical) concessive clause, while the phrase ö бot $\dot{\varepsilon} \xi$ हैe $\gamma \omega v$ vó $\mu \circ v$ is

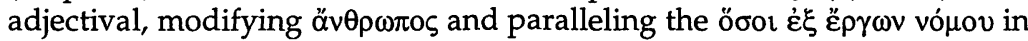
Gal. 3:10. Paul does not confront Peter with a new insight here, but builds on Peter's acknowledgement that even 'a person of the works of the Law' is not justified except through faith. If that is so, Paul continues, we are justified by faith, and not through 'works of the Law'. See J.D.G. Dunn, 'Yet Once More "The Works of the Law"; A Response' JSNT 46 (1992) 114. ${ }^{34}$ Rom. 2:26.

35 Pace Westerholm, op. cit., 119; Schreiner, op. cit., 228-9. When in Romans Paul broadens the sphere of application of the topic of justification, he does it under the category of 'faith', not 'works' (Rom. 11:20). See Seifrid, op. cit., 224-49. 
question, Paul twice clarifies (or, perhaps, redefines) the relation between 'grace' and 'works' for his audience at Rome, arguing that recompense for works by its very nature excludes grace. ${ }^{36}$ Yet his argument remains within the scope of Judaism.

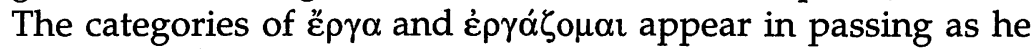
elaborates his understanding of the experiences of Abraham and Israel, both of which were bound up with the issue of the Law. 37

At the same time, Dunn's insistence that circumcision

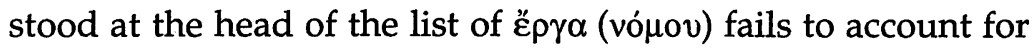
the distinction between the two that Paul presupposes. In Romans 4, having already appealed to Abraham as an example of justification of the ungodly apart from 'works', Paul addresses circumcision as a new issue. ${ }^{38}$ Moreover, his use of

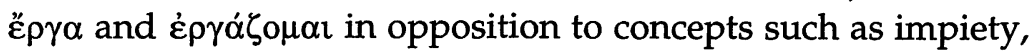
transgression, and forgiveness indicates that he here takes up

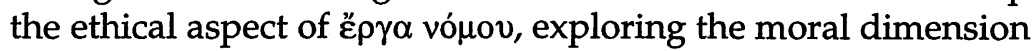
of covenant fidelity, and emphasising it by the slight shift in language. 'Circumcision' was in a sense distinct from 'works of the Law' because it was a sign (Rom. 4:11), emblematic of

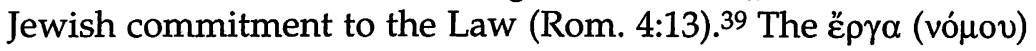
which the circumcised were to perform marked the difference between the righteous and the ungodly.

Further features of Galatians and Romans suggest that although the polarity between the universalism of the Gospel and Jewish particularism represents an important element of Paul's argumentative situation, it falls short of doing justice to the whole. Above all else, it fails to account for the strong attraction the message of the agitators had for the Galatian believers. The letter contains no evidence that they had lost the assurance of their salvation. They seem rather to have been attracted to Judaism in and of itself, as a supplement to their faith and a way to order their moral and religious universe, just as other Gentiles elsewhere, like Izates, had been drawn to a

\footnotetext{
36Rom. 4:4; $11: 6$.

37 See especially Rom. 4:5-8, where Paul moves directly from Abraham to David's transgression of the Law.

38Rom. 4:9-25.

${ }^{39}$ See also Rom. 2:17-29; 3:1; 3:27-31.
} 
full commitment to Jewish monotheism. Moreover, when we turn to Romans, we find a paradoxical relation between universalistic and particularistic themes. ${ }^{40}$ Without diminishing the stress of Romans 3-4 and Romans 10 on the universal scope of the Gospel, Paul elsewhere in the letter is intent on gaining Gentile submission to Jewish monotheism. The manner in which he introduces his Gospel is unashamedly Jewish, as is the way in which he closes the massive theological argument, (in my view) affirming the final salvation of ethnic Israel. His summary appeal in Romans 12:1, 2 calls for the submission of his primarily Gentile audience to the one God of Israel. His apostolic task, as he describes it to these readers, is to present the Gentiles as a priestly offering to Israel's God. ${ }^{41}$ They, as Gentiles, are indebted to the saints of Jerusalem. ${ }^{42}$ And perhaps most significantly, as a response to the Messiah's acceptance of them as Gentiles, they are to welcome those conservative Jewish Christians whose national practices might have been an embarrassment. 43

All these observations give us reasons for thinking that in rejecting '̌ $\rho \gamma \alpha$ vó $\mu o v$ as a guarantee of salvation, Paul rejects a moral superiority gained by obedience, notwithstanding that Jews who adopted such a stance would have attributed their progress to God's gracious covenant with Israel. There may well have been a distant echo of Luke's Pharisee at prayer in Paul's past which he also heard in his opponents at Galatia: 'God, I thank you that I am not like other human beings'. Bultmann's picture of the Jew consciously striving to secure righteousness through self-effort is a caricature. But it is equally a caricature to reduce Paul's debates in Galatians and Romans to a matter of Jewish ethnic privilege.

\footnotetext{
40See Nils Dahl, 'The One God of Jews and Gentiles' in Studies in Paul (Minneapolis: Augsburg, 1977) 178-91.

41Rom. 15:16.

42Rom. 15:27.

43Rom. 14:1-15:13.
} 


\section{Christ as the End of Paul's Experience of Exile}

Just as Dunn's idea of a 'national righteousness' has provided a criterion of discontinuity between Paul and the Judaism he knew within the paradigm of 'covenantal nomism', Wright has supplied an element of continuity: in his view, second-temple Judaism nearly universally saw itself in a continuing state of sin and exile, despite the return to the land. For Paul, faith in Christ resolved his deepest longing. The end of exile under pagans arrived in the representative death of the Messiah, who bore the curse of the Law for Israel on a Roman cross. Jesus' resurrection signalled the end of the exile and the promised ushering in of the nations to share in the eschatological blessings of the covenant. The breadth of scope and immense learning displayed in Wright's already published work on this topic call forth awe and admiration. There is much to be gained from both his The New Testament and the People of God and The Climax of the Covenant, in which he develops his work on the Jewish side of the equation and lays the groundwork of the Pauline side as well.

Nevertheless, Wright's proposal leads into another Sackgasse. As with Sanders' attempt to produce a comprehensive analysis of early Judaism, his approach breaks down in the details. The abstract pattern of the same 'text' or worldview behind virtually all the traditions of second-temple Judaism obscures the distinction between literature and life, missing the details that made all the difference for the storytellers. And the Greimasian analyses which Wright deploys, while helpful in themselves for decoding much of the literature of early Judaism for outsiders, do not distinguish between various understandings of the divine covenant with Israel that were of prime importance for insiders. 44 If, as outsiders, we had access to writings of the 'wicked priest' (and

44See especially Wright, New Testament and the People of God, 221-3; 371417. Equally seriously, this schema ignores those who enjoyed the reconstruction of the Temple, the Maccabean victories, Hasmonean rule, and even the status quo under the Romans-various forms of a 'theocratic' stream of tradition. Nor should we forget that there were many who did not leave literary deposits. 
$4 \mathrm{QMMT}$ may give some indication of what they would have been like), we would not see much difference between him and the 'teacher of righteousness' given Wright's model, but for a Qumran Essene it would have been darkness and light. More precisely stated: the early Jewish tradition of an extended period of exile for Israel is more complicated than recent advocates of this perspective often have taken into account. 45 Dissatisfaction with the condition of Jerusalem and the Temple is not precisely the same as the theme of a continuing exile. 46 And to view the exile as in some sense continuing is not the same as regarding 'all' of Israel as being in exile or estranged from God. 47 Variations in the use of the exile image suggest that it served as a rather fluid topos rather than as a settled and unchanging interpretation of Israel's experience. The obvious diversity of the pseudonyms in the array of works displaying the Deuteronomic sequence should not be overlooked: the implied authorial voice ranges from the antediluvian Enoch, to the twelve patriarchs, to the Mosaic Jubilees, to the exilic Baruch and Tobit, to the post-exilic Ezra. While the outworking of covenantal threats and promises in exile and restoration provides a generally consistent pattern through most early Jewish writings, the crucial narrative locations vary widely. Frequently, the authors (and presumably therefore, in some sense, their communities) are placed outside the image of the exile. They assume the role of the prophetic voice, implicitly excluding themselves (and those like them) from the

${ }^{45}$ See Michael Knibb, 'The Exile in the Literature of the Intertestamental Period', HeyJ 17 (1976) 253-72; James M. Scott, 'Restoration of Israel' in Gerald F. Hawthorne, Ralph P. Martin, Daniel G. Reid (ed.), Dictionary of Paul and His Letters (Leicester: IVP, 1993) 796-805; idem, 'For as Many as are of the Works of the Law are Under a Curse (Galatians 3.10)', in Craig A. Evans and James A. Sanders (ed.), Paul and the Scriptures of Israel (Sheffield: JSOT, 1993) 187-221. More nuanced are the treatments of Odil Hannes Steck, 'Das Problem theologischer Strömungen in nachexilischer Zeit', EvT 28 (1968) 445-58 and Donald E. Gowan, 'The Exile in Jewish Apocalyptic' in Arthur L. Merrill and Thomas E. Overholt (ed.), Scripture in History and Theology (Pittsburgh, Pickwick 1977) 205-23.

${ }^{46}$ The watershed passage itself, Dan. 9, focuses on the condition of Jerusalem, not the gathering of the exiles.

47In a stimulating conversation, my senior colleague, Marvin Tate formulated the issue in this helpful way. 
envisioned waywardness and decline of the people. As Steck observes, in the early Jewish materials the present is often the time for repentance prior to the arrival of the eschaton, when the righteous and sinner are distinguished.48 The Testaments of the Twelve Patriarchs, for example, represent a moralising piety expressed through the patriarchs who warn and reproach the subsequent generations for their coming depravity. One may go further. A number of works, sometimes those ostensibly set in the exile itself, display a considerable measure of confidence in the Law as the guarantee of salvation. The book of Baruch may well regard the exile as having ended already. We should not forget that the 'today' of the exile is simply a literary setting. The work celebrates Israel's unique possession of wisdom in Torah and ends on a triumphal note, suggesting that the author saw the end of the exile already progress ('Look your children are coming!' 4:37). For Sirach wisdom resides in Israel and has never been sent away. ${ }^{49}$ To characterise Tobit 14:5-7 as reflecting the idea of a continuing exile is slightly gratuitous. The text affirms that by God's mercy some will return from exile to the Land, to be joined by all at the 'times of fulfilment'. For the original audience, the first stage had been accomplished already. The same may be said more strongly of the prayer of Nehemiah in 2 Maccabees 1:2729 ('Plant your people in your holy place'), which looks forward to its fulfilment within the course of the narrative (2 Macc. 15:37, 'from that time the city has been in the possession of the Hebrews. So here I will end my story'). The Psalms of Solomon represent a similar viewpoint: the feet of the pious are standing quite firmly within the gates of Jerusalem, watching as the godless are removed and hoping for the Messiah to come and finish the task. The Qumran group regarded the end of the

48Odil Hannes Steck, Israel und das gewaltsame Geschick der Propheten (WMANT 23; Neukirchen: Neukirchener, 1967) 187. He points to the Apocalypse of Weeks, the Animal Apocalypse, Jubilees, and 4 Ezra among other works.

${ }^{49}$ See Sir 24, cf. BAR 4. Despite the Deuteronomic echoes in the Prayer of Sir 36:1-17, there is no confession that 'all' of disobedient Israel awaits a divine restoration: 'Reward those who wait for you and let your prophets be found trustworthy' $(36: 21)$. 
exile to have arrived in the community, perhaps uniquely, since they so fully assume for themselves the identity of Israel. As Wright himself observes, Essenes in Paul's day most likely were not waiting for the end of the exile, they had found it long ago: 'I thank you Lord, for you have redeemed my life from the pit and from the Sheol of the dead; you have raised me up to an eternal height'.50 This small sample of texts suggests not a widespread conviction, but a range of views on the status of Israel, which varied with time, place, and argumentative purpose. ${ }^{51}$ For all the wrestling with the covenant-faithfulness of God in the face of sin and evil that appears in the eschatologically-oriented writings of early Judaism, they are a long way from sounding like a united chorus of ' $\mathrm{O}$ Come, $\mathrm{O}$ Come Emmanuel'.

Ultimately what matters is whether a perception of a continuing exile substantially influenced Paul the Pharisee. Did the cross provide the solution to the plight in which he and other Jews saw themselves? Or was it faith in the crucified and risen Christ which first revealed to Paul the nature and extent of his lost state? The sort of continuity Wright has proposed in the 'end of the exile' theme makes it difficult to account for the 'word of the cross' as an occasion for stumbling. ${ }^{52}$ Where is the scandal, if the once crucified Messiah, now risen and vindicated, has ended Israel's exile? One doubts that the answer lies in simple Jewish disagreement with Paul's inclusivity of Gentiles, which did not have to do with 'openness' to outsiders but with how one secured faith in the one God. The question of circumcision is distant from the 1 Corinthians passage, which speaks to the response of Jews themselves to the proclamation of Christ. Although James Scott has appealed to a number of passages in favour of a position like that of Wright, none of the texts he cites suggest a commonly-held belief so much as a 'recollection' of the Deuteronomic pattern intended as an argument for Paul's

501QH 3:19, 20.

51The examples which Wright himself chooses to illustrate his point vary quite widely in this matter, The New Testament and the People of God, 269-70.

521 Cor. 1:18-25. 
readers. 53 Moreover, when we consider Paul's brief autobiographical remarks, we can have no confidence that Paul embraced a tradition that 'all' Israel was in exile prior to his conversion. Rather than bemoaning the state of his people or their domination by Rome, what we know of Paul prior to his conversion points to his having regarded himself as part of the circle of the faithful who waited in confidence for the day of judgement. He did not lament his covenantal failures, but rejoiced in the righteousness that was his through the Law. ${ }^{54}$ He did not despair over the shortcomings of his contemporaries, but sought to advance beyond them in 'Judaism'. Rather than embracing the early Christian proclamation, he regarded it as a threat, and zealously sought to guard against its corruption of the Jewish community. ${ }^{55}$ With other proponents of the 'new perspective' Wright rejects the notion that Paul lived with an anguished conscience under the Law prior to faith in Christ. Now instead, according to Wright, he anguished over the condition of the Jewish people. The Paul

${ }^{53}$ Contra Scott, 'Restoration', 801, I fail to see how 1 Thes. 2:15-16 reveals a sustained conviction that Israel had long been apostate. Without a doubt, it echoes Neh. 9:26, but it represents a judgement derived from what happened to Jesus and those who proclaimed him, probably reflecting Synoptic tradition and very likely referring to Christian prophets (Mt. 23:34, Lk. 11:49). Much the same may be said in regard to Gal. 3:10, cf. Scott 'Galatians 3:10', 194-221. Paul's Gentile readers, attracted to Judaism as they were, would not have shared in the pessimistic view expressed in the reference to Dt. 27:26. Moreover, the claim that Paul appeals to an accepted Deuteronomic curse on Israel fails to account for a substantial

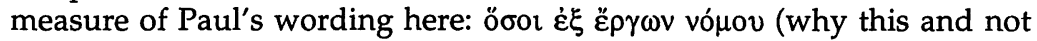
simply 'Israel'?), the stress on $\pi \alpha \hat{\varsigma}$ ('cursed is everyone who does not remain in all that is written'; while the LXX also used $\pi \hat{\alpha} \varsigma$, differences in wording make it doubtful that Paul is following it here), and above all else the fact that Paul finds it necessary to write 3:11, using Hab. 2:4 to show that one is not justified through the Law. The Deuteronomic pattern in Paul's letters, to which Scott has called attention, is helpful in explaining Paul's hope for Israel, but Paul's judgement on Israel is derived from the cross, and does not represent a continuation of a pre-conversion belief. See now J.M. Scott, 'Paul's Use of Deuteronomic Tradition', JBL 112 (1993) 645-655; and R.H. Bell, Provoked to Jealousy: The Origin and Purpose of the Jealousy Motif in Romans 9-11 (Tübingen: Mohr, 1993).

54Phil. 3:4-6.

55Gal. 1:13-14. 
of the introspective conscience is ushered out the door, while the Paul of the social conscience is welcomed in. With a curious and ironic twist, an early twentieth-century existentialist Paul is replaced by a late twentieth-century Paul disturbed by the malaise of the world.

In fact, the 'exile' motif appears to have functioned for Paul in a manner precisely opposite to that which Wright and Scott have proposed. It is absent from Paul's autobiographical statements about his pre-conversion status, and present in his interpretation of the problem of Israel in the light of faith in Christ. Paul's 'remnant' language emerges in the theodicean rhetoric of Romans 9-11 not as a simple continuation of the past, but in conjunction with the decisive enactment of the divine word of judgement on Israel.56 In the present time ( $\dot{\varepsilon} v \tau \hat{\omega}$

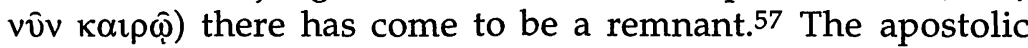
proclamation of Christ to the Gentiles brings about the provocation to jealousy 'by a nation which is not'.58 For Paul, the advent of the Messiah did not bring an end to Israel's continuing exile, but began it anew: 'Behold I lay in Zion a stone of stumbling and a rock of offence'.59 The disobedience with which Paul charges Israel represents not just a continuation, but a repetition of Israel's earlier refusal of God's saving mercy. ${ }^{60}$ Israel's past is not one of unqualified rebellion, 'they have zeal for God', yet Israel has failed to submit to the righteousness of God in Christ.61 On account of the Gospel, they have become enemies. 62 This conviction stands behind Paul's use of the figure of the olive tree branches, broken off because of their unbelief.63 As Käsemann has argued, Paul

$56^{\prime}$ Although the number of the children of Israel should be as the sand of the sea, the remnant shall be saved, for the Lord shall enact his word fully and decisively upon the land', Rom. 9:27-8; Is. 10:22; 28:22; cf. Rom. 11:5.

57Rom. 11:5.

58Rom. 10:19; Dt. 32:21.

${ }^{59}$ Rom. 9:33; Is. 28:16.

60Rom. 10:21; Is. 65:2.

${ }^{61}$ Rom. 10:2-4.

62Rom. 11:28.

63Rom. 11:20. 
interprets the history of salvation through the lens of Christ, not the reverse. 64

\section{Retracing Our Steps from Sanders' Reading of Paul}

Regardless of what one thinks of 'thin and tired' categories of Lutheran polemic, Luther has undeservedly acquired a very bad name in much of the revisionist work. 65 Sanders' choice of the term 'covenantal' to describe the thought of early Judaism is striking because Luther himself was reacting to a pactum theology, in which divine saving action is formally primarybringing one into a state of grace and subsequently sustaining one there-but materially dependent on human response and 'maintenance of covenant status'. Sanders' 'covenantal nomism' is at root quite similar to the medieval understanding of facienti quod in se est Deus non denegat gratiam, particularly in the via moderna. ${ }^{66}$ God gives his grace to the one who by effort and intent is faithful to the covenant. True, there is a variation in emphasis which should not be overlooked. The theology of the via moderna tended to create doubts: one could not know with certainty whether one had done true penance and was in a state of grace. In contrast, everywhere we turn in the early Jewish sources there is an assurance of God's covenantal favour. Not even 4 Ezra is an exception. ${ }^{67}$ The psychology of the sinner is entirely peripheral to the issue, however. For Luther, and for Paul whose letters he pondered, the question is where the salvation of the human being ultimately lies: Is it in some practice, disposition, or quality arising within the human being by the assistance of divine grace, or is it fully and radically $a b$ extra? Does God find within us some inherent receptivity to

${ }^{64}$ Ernst Käsemann, 'Rechtfertigung und Heilsgeschichte im Römerbrief', in Paulinische Perspektiven (Tübingen: Mohr [Siebeck], 1969) 108-39.

65Wright, 'Paul of History', 87.

665ee Alister McGrath, Iustitia Dei: A History of the Christian Doctrine of Justification (Cambridge: CUP, 1986) 1:70-91. For the sharpest, and yet entirely fair statement of this matter, which so far has been ignored by proponents of the 'new perspective', see Silva, op. cit., 347-9.

${ }^{67}$ There too we find a circle of those who have kept the ways of the Most High. See 43 Ezra 7:1-140; 12:1-51. 
grace by which he remoulds our corruption, or must he put to death in order to raise to life?

In reality, Luther's theology of the cross and his defence of a iustitia aliena marked a radical departure from the introspection of the medieval theology of humility. 68 And the Pauline article on justification as it was once adopted by the Reformers is absolutely opposed to the privatism rooted in our secularised Western society. Sanders and those who have followed him have trod down the wrong path because they have followed modern anthropological categories, exploring grace no further than the superficial level of doubt and assurance. Paul's understanding of grace reaches its profundity by being before all else objective and theocentric. The fallen world, whether it knows it or not, lies beneath the wrath of God, which already is giving over pagans to immorality, and waits with terrible anger for those confident moralists (read: us) who by their (our) self-centred dealings with others reveal that they (we) have loved idols as well. The gift of justification is likewise objective and external: now manifest apart from the Law, in Jesus Christ whom God set forth openly as a $i \lambda \alpha \sigma \tau$ in then, that the forensic understanding of justification in Paul's letters is 'individualistic' in a privatistic sense is completely erroneous. On the contrary, it strips us of any hiding place and sets us in foro Dei, to be damned for our idolatry and selfishness, and to be graciously forgiven and given Christ as our Lord, as Käsemann forcefully reminded us.69 Or as Paul

68See Martin Brecht, Martin Luther: His Road to Reformation 1483-1521 trans. James L. Schaaf (Minneapolis: Fortress, 1985) 221-37; Walther von Loewenich, Luthers Theologia Crucis (ed. 5; Witten: Luther, 1967); Joseph Vercruysse, S.J., 'Luther's Theology of the Cross at the Time of the Heidelberg Disputation', Gregorianum 57 (1976) 523-48; James Nestingen, 'Luther's Heidelberg Disputation: An Analysis of the Argument', in A.J. Hultgren, Donald Juel, Jack D. Kingsbury (ed.), All Things New: Essays in Honor of Roy A. Harrisville (Word and World Supplements Series 1; Minneapolis: Fortress 1992) 147-51. I must thank my colleague Marvin Anderson for his bibliographical assistance, and his guidance in this question.

${ }^{69}$ Ernst Käsemann, 'Gottesgerechtigkeit bei Paulus', in Exegetische Versuche und Besinnungen (ed. 2; Göttingen: Vandenhoeck \& Ruprecht, 1965) 2:181- 
says, 'Each of us lives or dies to the Lord, for to this end Christ died and lived again, that he might be Lord of the dead and of the living'. ${ }^{70}$ To attempt to correct the personal nature of forensic justification by 'reversing' direction toward social justice is to remove the article on which all true justice hangs: the wrath and love of God manifest in the justifying work of the cross which call us to account not merely for our outward deeds, but for the secrets of our hearts. ${ }^{71}$

As is obvious from the thought of the Reformers, the search for a gracious God is inherently joined to the question of what constitutes the true Church. Luther's breakthrough was nothing other than the confession of the freedom of God over against the visible Church to save 'his own little flock' wherever the Gospel is proclaimed.72 Rather than standing in opposition to the corporate dimension of Christianity, the article on justification provides its necessary precondition. True universalism is impossible without hearing in the Gospel that one stands condemned and graciously redeemed coram Deo. Otherwise one sees oneself falsely only as a member of a victorious or victimised circle of the pious: self-love and idolatry in either case. Paul's letter to Rome displays this understanding. His admonition to the Gentile majority, that they must freely accept the 'weak', is just as much an outworking of his argument on justification as his earlier address to the Jewish minority regarding the Gospel's scope. And Paul emphasises to them that the end of Israel's 'new' exile was yet to come in the appearance of the deliverer from Zion. ${ }^{73}$

93. While Käsemann's collapsing of the conceptual categories of 'declare righteous' and 'make righteous' is flawed, he rightly sees that for Paul an unbreakable link exists between them. To distinguish between the two is essential, to separate the two is fatal.

70Rom. 14:7-9.

${ }^{71}$ Contra Dunn, 'The Justice of God: A Renewed Perspective on Justification by Faith', JTS 43 (1992) 21-22.

72 See Brecht, op. cit., 349-388.

${ }^{73}$ Here Wright and I disagree on the reading of Rom. 11:25-27. I am still persuaded that this passage reflects the expectation of an eschatological salvation of the nation of Israel. That reading best accounts for the repeated temporal references ('a partial hardening has come about for Israel, until the fullness of the Gentiles has come in', 11:25; 'this shall be 
This elaboration of Israel's eschatological salvation was of critical importance to a church of a few Jews and many Gentiles. It reinforced for Paul's Gentile readership their limited place in the working out of salvation in history: 'you stand by faith; do not be conceited, but fear' ${ }^{74}$ At the very point at which Paul is the most universal, he is radically particular. Only in the God of Israel's freedom to imprison all humanity in its disobedience, does God remain God. God otherwise becomes subject to Gentile ideals. Or, as Käsemann has warned, otherwise we save ourselves by means of salvation-history: our triumphalist or pious narratives that remove us from the searching judgement of the cross. ${ }^{75}$ Carl Braaten has rightly raised the question as to whether the current shift in interest from individualistic soteriology to ecclesiology may not simply represent the exchange of one kind of narcissism for another.76 The article on justification warns us away from that constant temptation to replace the word of the cross with our community as the vehicle of salvation for the world. Rightly understood, it remains the article by which the Church stands or falls.

my covenant whenever I take away their sins [indefinite time, but not iterative, since it is joined to the Redeemer's coming from Zion]', 11:27), Paul's disclosure of this event as a mystery (11:25), and the distinction Paul draws in 11:28 between the Gospel and God's election of Israel.

${ }^{74}$ Rom. 11:20, cf. 11:25.

75Käsemann, 'Rechtfertigung und Heilsgeschichte', 112.

76Carl E. Braaten, Justification: The Article by Which the Church Stands or Falls (Minneapolis: Fortress, 1990) 10. 